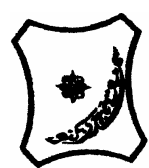

Bayero Journal of Pure and Applied Sciences, 6(2): 118 - 120

Received: June 2013

Accepted: October 2013

ISSN $2006-6996$

\title{
COMPARATIVE PROXIMATE COMPOSITION AND ANTIOXIDANT VITAMINS CONTENTS OF TWO HONEY VARIETIES (LIGHT AMBER AND DARK AMBER) FROM SOKOTO STATE, NIGERIA
}

\author{
*Wasagu, R.S.U., Shehu, S. and Mode, Y.D. \\ Department of Biochemistry, Faculty of Science, Usmanu Danfodiyo University, Sokoto, Nigeria. \\ *Correspondence author: rsuwasagu282@gmail.com
}

\section{ABSTRACT}

The proximate composition and antioxidant vitamins analysis of two varieties of honey (dark amber and light amber) were carried out using standard methods. The values for moisture, ash, crude lipid, crude protein and crude carbohydrate contents of the two honeys, (light amber and dark amber) are $9.39 \pm 0.15,0.55 \pm 0.05,1.51 \pm 0.11,1.64 \pm 0.06 a n d 86.89 \pm 0.93 \%$ (for light

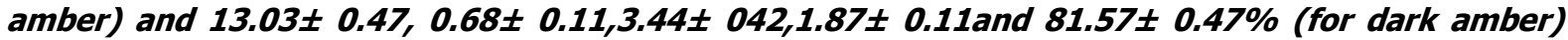
respectively, while fibre was not detected in both samples. Both samples showed high amount of carbohydrate, that of light amber being higher. The antioxidant vitamins (vitamins $A, C$ and $E$ ) content of the two honeys are $4.08 \pm 0.21,2.22 \pm 0.10 a n d 0.28 \pm 0.03(\mathrm{mg} / \mathrm{dl})$, (for light amber), and 4.42 $\pm 0.06,2.61 \pm 0.11$,and $0.26 \pm 0.02$ ( $\mathrm{mg} / \mathrm{dl})$, (for dark amber) respectively. Both samples showed high content of Vitamin A, with that of dark amber being higher. The results suggest that both honeys are nutritionally good source of energy and possess some antioxidant vitamins.

Keywords: Comparative, proximate composition, antioxidant vitamins, honey

\section{INTRODUCTION}

Honeyconsists basically of a complex mixture of carbohydrates, especially glucose and fructose, organic acids, amino acids, minerals, vitamins, enzymes, pollens, and pigments (Schrammet al., 2003). It is a mixture of concentrated aqueous solution of inverted sugars and complex mixture of other saccharides, amino acids, proteins, organic acids, vitamins, minerals, Maillard reaction products and both enzymatic and non enzymatic antioxidants, including glucose oxidase, catalase, ascorbic acid, flavonoids, phenolic acids and carotenoid derivatives (Almamary et al., 2002; Gheldofand Engeseth, 2002). Its nutritional quality, medicinal, and sensory properties have attracted thousands of consumers (Carlos et al., 2009).

The honeybee (Apis mellifera) is the specie that produces large quantity of honey in Dange town, Sokoto State, Nigeria.Bees obtain all their nutritional components from nectar, pollen and water. Nectar is reduced to honey containing predominantly carbohydrates with very little protein, vitamins and minerals (Yaghoobiet al., 2008). Whiteland Doner (1980) reported that fully ripened honey consists of levulose/fructose (41\%) and dextrose / glucose 35\% and 22others, which are more complex than the monosaccharides present in quite minute quantities. Of the 22 complex sugars, the oligosaccharides identified are maltose, isomaltose, maltulose, nigerose, turanose, kojibiose, laminarihiose, a, $\beta$ trehalose and gentibiose. Ten trisaccharides are present: melezitose, maltotriose, 3 -aisomaltosylglucose1-ketose, panose, isomaltotriose and isomaltopentaose. Most of these sugars do not occur in nectar but may arise from enzymes added by honeybee during honey ripening or by chemical action in the concentrated acid sugar mixture of honey (Gheldof et al., 2002).

The presence of phytochemicals such as flavonoids and phenolic acids, may suggest the role of honey, along with fruits and vegetables, as a nutritional source of natural antioxidants responsible for protecting human health as was earlier reported (Gheldof et al.,2002; McKibben and Engeseth 2002;Schrammet al., 2003;Tonkset al., 2001 and Tonks et al., 2003). Its antibacterial, antiinflammatory, antioxidant and anticancer properties have been extensively discussed (Orsolicet al.,2005; Swellam et al., 2003; Blasaet al., 2006 and Board, 1972).Vitamin $\mathrm{C}$ and most of the vitamin B complex are present in variable amounts (Oszmianski and Lee, 1990). Apart from being a high-energy substance, honey has high digestibility, high acidity as well as high taste appeal. By this characteristic antioxidant property, honey when applied at $10 \%$ has been found to inhibit enzymatic browning in apple slices and grape juice (Khan, 1985).This study was designed to investigate the proximate composition and antioxidant properties of two varieties of honey samples obtained from Dange Shuni local government area of Sokoto State, being the predominant producer of honey around the Metropolis.

\section{MATERIALS AND METHODS}

\section{Collection of the Sample}

The two varieties of honey (dark amber and light amber) were obtained from Dange central market in Dange town, Sokoto State, Nigeria. 


\section{Proximate Chemical Composition and Trace Elements Estimation}

Nutritional compositions of the two honey samples were estimated with standard techniques. Moisture content (AOAC, 1990), ash (Oyenuga, 1987), crude protein by Micro kjehdahl method (AOAC, 1990), crude lipid by Soxhlet method, crude fibre (AOAC method, 1990), carbohydrates (by difference), vitamin A (Lowry et al., 1983), vitamin C (Tillmans method, 1930) based upon the reduction of the dye (2,6-dichlorophenolindophenol) by an acid solution of ascorbic acid, determined by titration and vitamin E by colorimetric method (Lowry et al., 1983) based on the reduction of ferric ions to ferrous ions, which form red colour with dipyridyl. The ash solutions were prepared with wet digestion (Raganna, 1986).

The results were expressed as means \pm standard deviations of three replicate determinations.

\section{RESULTS AND DISCUSSION}

The results of proximate composition (Table 1), shows both samples have high carbohydrate content $(86.89$ \pm 0.93 and $81.57 \pm 0.47 \%$ ) and high moisture (9.39 0.15 and $13.03 \pm 0.47 \%$ ) for light amber and dark amber, respectively. This suggests honey to be a good source of energy (especially for the diabetic patients because of its high fructose content). The protein (1.64 \pm 0.06 and $1.87 \pm 0.11 \%$ ) and lipid $(1.51 \pm 0.11$ and $3.44 \pm 0.42 \%)$ contents for light amber and dark amber respectively are relatively low, indicating that honey is not a good source of protein and some amino acids. This is in support of the earlier finding which stated little protein content in honey (Postmeset al., 1995).

The small amount of ash content $(0.55 \pm 0.05$ and $0.68 \pm 0.11 \%$ ) also suggests that honey contains small amount of minerals like $\mathrm{Ca}, \mathrm{Mg}, \mathrm{Fe}, \mathrm{K}, \mathrm{Na}$ etc. These results are in consonance with reported values of $17.1 \%$ water, $82.4 \%$ carbohydrates, $38.5 \%$ fructose, $31 \%$ glucose and $12.9 \%$ other sugars and $0.5 \%$ proteins, amino acids, vitamins, phenolic compounds, organic acids and multiple minerals, among other minority constituents (White and Doner1980; Garcia et al., 1986; Garrett and Grisham, 2001 and Montenegroet al., 2003).

The concentrations of vitamins $A, C$ and $E$ as $4.08 \pm$ $0.21,2.22 \pm 0.10$ and $0.28 \pm 0.03 \mathrm{mg} / \mathrm{dl}$ for light amber and 4.42 $\pm 0.06,2.61 \pm 0.11$ and $0.26 \pm 0.02$ $\mathrm{mg} / \mathrm{dl}$ for dark amber respectively, showed both honeys to containrelatively high amounts of vitamins $A$ and $C$ indicating possession of antioxidant properties by both samples, as well as good for maintenance of normal vision. This conforms to Satyanarayanaand Chacrapani(2008) report, that honey contains high amounts of vitamin A.

On comparative basis, the study revealed that light amber honey contains more carbohydrates than dark amber honey while the latter contains more protein, lipid, moisture and more vitamins $A$ and $C$ than the former. This suggests dark amber honey to be better than light amber honey in terms of nutritional value as well as antioxidant potential.

Table 1: Proximate composition of the two honey varieties

\begin{tabular}{|c|c|c|c|c|c|c|}
\hline SAMPLES & \multicolumn{6}{|c|}{ PARAMETERS (\% Composition) } \\
\hline & Moisture & Ash & Protein & Lipid & Fibre & Carbohydrate \\
\hline Light Amber & $9.39 \pm 0.15$ & $0.55 \pm 0.05$ & $1.64 \pm 0.06$ & $1.51 \pm 0.11$ & ND & $86.91 \pm 0.93$ \\
\hline Dark Amber & $13.03 \pm 0.47$ & $0.68 \pm 0.11$ & $1.87 \pm 0.11$ & $3.44 \pm 042$ & ND & $80.98 \pm 0.47$ \\
\hline
\end{tabular}

The values are expressed as means \pm Standard Deviation $(n=3), N D=$ Not Detected

Table 2: Antioxidant vitamins contents of the two honey varieties

SAMPLES VITAMINS(mg/dl)

\begin{tabular}{llll}
\hline & Vitamin A & Vitamin C & Vitamin E \\
LIGHT AMBER & $4.08 \pm 0.21$ & $2.22 \pm 0.10$ & $0.28 \pm 0.03$ \\
DARK AMBER & $4.42 \pm 0.06$ & $2.61 \pm 0.11$ & $0.26 \pm 0.02$ \\
\hline
\end{tabular}

The values are expressed as means \pm Standard Deviation $(n=3)$

\section{CONCLUSION}

Both honeys are a good source of energy and natural antioxidants. Honey is therefore, considered to be a valuable food and medicinal material, that nourishes,

\section{REFERENCES}

Al-mamary, M., Al-meeri, A. and Al-Habori, M. (2002). "Antioxidant activities and total phenolics of different types of honey". Nutrition Research. 22: 1041-1047.

AOAC (1990).Official Methods of Analysis (16 ${ }^{\text {th }}$ Edition) of Association of Official Analytical Chemists, Washington D.C.

Blasa, M., Candiracci, M., Accorsi, A., Piacentini, M. P., Albertini, M. C. and Piatti, E. (2006). "Raw heals as well as protects the body againstcertain diseases, with dark amber honey having more potentials than light amber.

Millefiori honey is packed full of antioxidants". FoodChem.97: 217-222.

Board J. (1972) "Honey Natural Food and Healer". Macmillian Publishing Co. pp 9 - 14.

Carlos, A.L., Carvalho, G.,Sodre, S., Antonio, A.O., Fonseca, R. M.O.,Alves, B. A. and Souza, L. C. (2009) "Physicochemical characteristics and sensory profile of honey samples from stingless bees submitted to a dehumidification process". An. Acad. Bras. Cienc. 81:1 
Garcia, A., Soto, D. and Romo, C. (1986). La miel de abejas, composicion quimica, propiedadesyusos industriales. Revista Chilena de Nutricion.14: 185-191.

Garrett, R.H., and Grisham, C.M. (2001). "Principles of Biochemistry" with a Human Focus. Brooks/ Cole, USA. P. 223-225.

Gheldof, N. and Engeseth, N. J. (2002). "Antioxidant capacity of honeys from various floral sources based on the determination of oxygen radical absorbance capacity and inhibition of in vitro lipoprotein oxidation in human serum samples". J, Agric Food Chem.50:3050-3055.

Gheldof, N., Wang, X. H. and Engeseth, N. H. (2002). "Identification and quantification of antioxidant components of honeys from various floral sources".J. Agric. Food Chem. 50: 5870-5877.

Khan, V. (1985). "Effects of Proteins, Protein hydrosylates and amino acids on dihydroxyphenolase activity of polyphenoloxidase of mush room avocado and banana". J. Food Sci.50: 111-115.

Lowry, S. E., Robert, L. H., Lehman, I. R., Lefkotz, R. J., Hamher, P. and White, A. (1983). Mammalian Biochemistry, $3^{\text {rd }}$ edn. McGrawHill Book Co. (UK). Pp 666-676

McKibben, J. and Engeseth, N. J. (2002). "Honey as a protective agent against lipid oxidation in ground turkey". J. Agric Food Chem.50:592595.

Montenegro, G. R., Pizarro, G., Avila, R., Castro, C., Rios, O., Munoz, F. B. and Gomez, M. (2003).Origen botanico y propiedadesquimicas de lasmieles de la Region MediterraneaArida de Chile.Ciencia e Investigacion Agraria.30: 161-174.

Orsolic, N., Terzic, S., Sver, L. and Basic, I. (2005)."Honey-bee products in prevention and/or therapy of murine transplantable tumours ".J.Sci. Food Agric.85:363-370.

Oszmianski, J. and Lee, C. Y. (1990)."Inhibition of Polyphenoloxidase activity and browning by honey".J. Agric Food Chem.38: 1892 - 1895.

Oyenuga, V.A. (1987). "Nigerians, Food and Feeding Stuff". University Press Ibadan, Nigeria. Pp. 106-108.

Postmes, T.,Bogaard, A. E. and Hazen, M. (1995). "The sterilization of honey with cobalt 60 gamma radiation: a study of honey spiked with spores of Clostridium botulinum andBacillus subtilis".Experientia.51: 986989.

Raganna, S. (1986). "Handbook of Analysis and Quality Control for fruit and vegetable products". Tata mcGrow Hill.

Satyanarayana, U. andChakrapani, U. (2008): "Essential of Biochemistry" $2^{\text {nd }}$ edition. Books and allied (P) Ltd. Kolkata, India.Pp. 118-132
Schramm, D. D., Karim, M., Schrader, H. R., Holt, R. R., Cardetti, M. and Keen, C. L. (2003). "Honey with high levels of antioxidants can provide protection to healthy human subjects". J. Agric FoodChem.51:1732-1735.

Swellam, T., Miyanaga, N., Onozawa, M., Hattori, K., Kawai. K., Shimazui, T. (2003). "Antineoplastic activity of honey in an experimental bladder cancer implantation model: in vivo and in vitro studies". Int. J. Urol.10:213-219.

Tillmans, J. (1930). "The occurrence of vitamin $C$ in foods". Z. Untersuch. Lebensmitt. Pp. 34-60.

Tonks, A., Cooper, R. A., Price, A. J., Molan, P. C. and Jones, K. P. (2001). "Stimulation of TNF-a release in monocytes honey".Cytokine. 14:240-242.

Tonks, A. J., Cooper, R. A., Jones, K. P., Blair, S., Parton, J. and Tonks, A. (2003). "Honey stimulates inflammatory cytokine production from monocytes". Cytokine. 21:242-247.

White, J. W. Jr. and Doner, L. W. (1980), "Keeping". United States Agriculture Handbook. Revised edn. Pp $245=244$

Yaghoobi, N. N., Al-Waili, M. Ghayour, M.,Parizadeh, Z.,Abasalti, Z.,Yaghoobi, F., Yaghoobi, H., Esmaeili, S.M.R., Kazemi, B.R. Aghasizadeh, Saloom, K. Y. and Ferns, G. A. A. (2008). "Natural honey and cardiovascular risk factors; effects on blood glucose, cholesterol, triacylglycerole,CRP, and body weight compared with sucrose". The Scientific World Journal 8: 463-469. 